\title{
Genomic variability of Pantoea ananatis in maize white spot lesions assessed by AFLP markers
}

\author{
A.M. Miller ${ }^{1}$, J.E.F. Figueiredo ${ }^{2}$, C.L. Chaves ${ }^{1}$, E.A. Ruas ${ }^{3}$, M.I. Balbi-Peña ${ }^{1}$, \\ N.B. Colauto ${ }^{4}$ and L.D. Paccola-Meirelles ${ }^{1,4}$ \\ ${ }^{1}$ Departamento de Agronomia, Universidade Estadual de Londrina, Londrina, \\ PR, Brasil \\ ${ }^{2}$ Laboratório de Bioquímica Molecular, Embrapa Milho e Sorgo, Sete Lagoas, \\ MG, Brasil \\ ${ }^{3}$ Departamento de Biologia Geral, Universidade Estadual de Londrina, \\ Londrina, PR, Brasil \\ ${ }^{4}$ Laboratório de Biologia Molecular, Universidade Paranaense, Umuarama, \\ PR, Brasil \\ Corresponding author: L.D. Paccola-Meirelles \\ E-mail: paccola@uel.br \\ Genet. Mol. Res. 15 (4): gmr15049452 \\ Received October 18, 2016 \\ Accepted December 6, 2016 \\ Published December 19, 2016 \\ DOI http://dx.doi.org/10.4238/gmr15049452
}

Copyright (C) 2016 The Authors. This is an open-access article distributed under the terms of the Creative Commons Attribution ShareAlike (CC BY-SA) 4.0 License.

ABSTRACT. Measures to control maize white spot (MWS) caused by Pantoea ananatis are preferentially based on resistant cultivars. A lack of knowledge on the genetic variability of pathogens could interfere with the development and utilization of controlling strategies in this pathosystem. The main goals of this study were to investigate the genetic variability of $90 \mathrm{P}$. ananatis isolates from three different eco-geographical regions of Brazil by amplified fragment length polymorphism (AFLP), and to determine the presence of a universal $P$. 
ananatis plasmid in isolates from tropical Brazil. Analysis of genetic similarity by AFLP allowed us to categorize the 90 isolates into two groups. However, no correlation between the collecting sites and genetic groupings was observed. The polymorphism percentage found in $P$. ananatis ranged between 24.64 and $92.46 \%$, and genetic diversity was calculated to be $0.07-0.09$. The analysis of molecular variance showed that $99.18 \%$ of genetic variability was within the populations, providing evidence that evolutionary forces were acting on these populations. All $P$. ananatis isolates showed the $P$. ananatis universal plasmid (280 or $352 \mathrm{~kb}$ ). This is the first report on the presence of a universal $P$. ananatis plasmid from MWS lesions in the tropical area.

Key words: Allele genotyping; Maize disease; P. ananatis; Plasmid; Phytopathogenic bacteria; Polymorphism

\section{INTRODUCTION}

The current maize (Zea mays L.) production system in Brazil is susceptible to several diseases that significantly affect the quality and productivity of the farming culture (Oliveira et al., 2004). Among these diseases, the maize white spot (MWS), caused by Pantoea ananatis (Paccola-Meirelles et al., 2001; Gonçalves et al., 2013), has gained attention from researchers in recent years due to its geographical distribution and its potential to cause significant yield losses on susceptible cultivars.

Found in Brazil since the 1980s, the first stage of MWS disease starts with the onset of dark green aqueous lesions similar to anasarca, which rapidly progress to straw-colored necrotic lesions (Paccola-Meirelles et al., 2001). In general, the lesions are elongated and irregular, measuring 0.3$2.0 \mathrm{~cm}$ in length depending on the level of resistance of the cultivar (Paccola-Meirelles et al., 2001). Damages caused by MWS disease can exceed $60 \%$ of the total production in the Brazil (Pinto and Fernandes, 1995). According to Pereira et al. (2005), the main control strategy of MWS disease is based on the utilization of resistant genotypes, primarily in areas where weather conditions are more favorable to disease development. This strategy is the most secure and practical method of MWS disease management, and has minimal environmental impacts (Pereira et al., 2005). However, the development of resistant genotypes has been challenging due to the lack of knowledge of the genetic diversity of $P$. ananatis, resulting in inefficient and short-termed cultivar resistance. The resistance levels of a maize hybrid may vary in different environments, suggesting that genetic resistance to $P$. ananatis is unstable (Souza and Duarte, 2002).

Phytopathogenic bacteria cause high economic losses in many crops due to their fast dissemination, severe attacks, and difficulties in disease control (Romeiro, 2005). Moreover, the high adaptability of these pathogens allows them to survive under various weather conditions, different phenological phases of the host, and during chemical treatments (Romeiro, 2005). Therefore, knowledge of the evolutionary processes, pathogenic adaptations, as well as the genetic diversity of bacterial populations is important for the prediction and evaluation of management strategies, and for the development of disease control programs (Hanage et al., 2006).

The $P$. ananatis strain display a wide range of ecological adaptations, as they are frequently isolated from diverse and unrelated ecological niches (De Maayer et al., 2014). It is reasonable to assume that members of the Pantoea genus have been subjected to extensive

Genetics and Molecular Research 15 (4): gmr15049452 
genotypic diversifications. P. ananatis usually colonize the same ecological niche, but show distinct interaction strategies with the host plant (maize). They display low levels of genetic variability and exhibit different phenotypes (Sheibani-Tezerji et al., 2015). The $P$. ananatis genome is composed of one circular chromosome and an accessory megaplasmid, which is approximately 280-794 kb in length (Choi et al., 2012; De Maayer et al., 2012). High nucleotide sequence similarity $(>99 \%)$ has been observed among the core genomes of P. ananatis isolated from different sources and eco-geographical regions (Hara et al., 2012; De Maayer et al., 2014; Sheibani-Tezerji et al., 2015). Therefore, strain differentiation in $P$. ananatis arise from $<1 \%$ of the accessory genome.

The acquisition and maintenance of accessory genes on plasmids of bacteriophage via integration, horizontal gene transfer, and conjugation are responsible for genotype differentiation among many bacterial species (Jackson et al., 2011; Soares-Castro and Santos, 2014). The accessory genes often appear to move laterally between strains, thereby forming new trait combinations (Segerman, 2012). The extensive variety of transposases, integrases, and other mobile genetic elements in the accessory genome of $P$. ananatis indicate that horizontal gene transfer between strains has played potentially significant roles in the diversification of the $P$. ananatis genome (De Maayer et al., 2014). Nucleotide and protein comparisons among 20 LPP-1 plasmids from seven different Pantoea species, including pathogens, endophytes, and epiphytes in a wide range of plant and insect-associated strains were made (De Maayer et al., 2012; Hara et al., 2012). Results showed that LPP-1 plasmids are critical for adaptation of $P$. ananatis to diverse environmental conditions and ecological niches, and are vital for their abilities to act as pathogens, biocontrol agents, and saprophytes (De Maayer et al., 2012; Hara et al., 2012). Therefore, the large plasmid of Pantoea spp plays a crucial role in bacterial adaptation and functional diversification, thus driving strain differentiation (Hara et al., 2012). Information regarding the evolution of pathogen-host interactions is important for improving host resistance (Pereira et al., 2005).

Studies on genetic variability of $P$. ananatis in tropical maize are scarce. In a study performed in an eco-geographical area of Brazil, Lana et al. (2012) described a high genetic variability among isolates of three Pantoea species collected from the leaves of maize, sorghum, and crabgrass. The present study aimed to investigate the genetic variability within

$P$. ananatis isolates that cause MSW lesions in three maize-producing regions of Brazil via amplified fragment length polymorphism (AFLP). We also wanted to verify the existence of a universal Pantoea sp. plasmid in the respective isolates.

\section{MATERIAL AND METHODS}

\section{Collecting sites}

P. ananatis bacterial isolates (90) were obtained from MWS lesions according to protocol described by Paccola-Meirelles et al. (2001). These isolates were collected in three maize-producing areas, which represent distinct ecological regions in the south, southeast and central-west regions of Brazil (Table 1). The isolates were deposited into the Culture Collection of the Laboratory of Genetics of Microorganism of Universidade Estadual de Londrina.

\section{Genomic DNA extraction and molecular identification}

Genomic DNA of $P$. ananatis isolates was extracted according to steps outlined

Genetics and Molecular Research 15 (4): gmr15049452 
by Ausubel et al. (1987). The 16S-23S rRNA gene internal transcribed spacer region (approximately 360-388 bp) was amplified by polymerase chain reaction (PCR) with speciesspecific primers designed for $P$. ananatis. The primer sequences were as follows: ANAF (forward primer): 5'-CGTGAAACTACCCGTGTCTGTTGC-3'; ANAR (reverse primer): 5'-TGCCAGGGCATCCACCGTGTACGCT-3' (Figueiredo and Paccola-Meirelles, 2012).

PCR was performed in $25 \mu \mathrm{L}$ reaction mixture, which contained $2.5 \mu \mathrm{L}$ reaction buffer 10X (20 mM Tris-HCl, pH 8.4, $50 \mathrm{mM} \mathrm{KCl}), 1.0 \mu \mathrm{L} 50 \mathrm{mM} \mathrm{MgCl}, 1.0 \mu \mathrm{L} 3 \mathrm{mM}$ primer, $2.5 \mu \mathrm{L} 2.5 \mathrm{mM}$ dNTP mix, $0.5 \mu \mathrm{L}$ Taq DNA polymerase (Phoneutria, Brazil; $5 \mathrm{U} /$ $\mu \mathrm{L}), 1 \mu \mathrm{L} 20 \mathrm{ng} / \mu \mathrm{L}$ genomic DNA, and ultrapure water. The reactions were carried out in a thermocycler (TX96 Amplitherm) under the following conditions: denaturation at $95^{\circ} \mathrm{C}$ for $3 \mathrm{~min} ; 29$ cycles at $95^{\circ} \mathrm{C}$ for $30 \mathrm{~s} ; 58^{\circ} \mathrm{C}$ for $30 \mathrm{~s}$, and $72^{\circ} \mathrm{C}$ for $30 \mathrm{~s}$; final extension at $72^{\circ} \mathrm{C}$ for $10 \mathrm{~min}$. Amplified products $(10 \mu \mathrm{L})$ were resolved on a $1 \%$ agarose gel with TAE $1 \mathrm{X}$ buffer $(0.04 \mathrm{M}$ tris-acetate, $0.001 \mathrm{M}$ EDTA, $\mathrm{pH} 8.0)$ at $8 \mathrm{~V} / \mathrm{cm}^{2}$. The gels were stained with ethidium bromide $(0.5 \mathrm{mg} / \mathrm{L})$, visualized under ultraviolet light, and photographed with the photodocumentation System L-PIX EX (Loccus Biotechnology).

\section{Plasmid extraction}

Isolation of plasmid DNA was performed using a modified alkaline lysis protocol outlined by Kado and Liu (1981). Bacterial isolates were cultivated in $5 \mathrm{~mL}$ trypticase soy broth culture medium for $24 \mathrm{~h}$ at $28^{\circ} \mathrm{C}$. Cell concentration was standardized via spectrophotometry, where $\mathrm{OD}_{600}$ was approximately $0.3-5 \times 10^{8} \mathrm{CFU} / \mathrm{mL}$. Next, bacterial suspensions (1.5 $\mathrm{mL}$ aliquots) were centrifuged for $2 \mathrm{~min}$ at $16,435 \mathrm{~g}$. The pellets were suspended in $1 \mathrm{~mL}$ ultrapure water, further centrifuged, and resuspended in $50 \mu \mathrm{L}$ TAE buffer (1X) with agitation. Lysis solution $(350 \mu \mathrm{L})$ was added at $30^{\circ} \mathrm{C}$, and the resulting mixture was homogenized by inversion (3X) and further incubated for $15 \mathrm{~min}$ at $30^{\circ} \mathrm{C}$ without agitation. This was followed by addition of $800 \mu \mathrm{L}$ phenol:chloroform:isoamyl alcohol $(25: 24: 1)$. Samples were then vigorously shaken for 2 min until the color turned milky-white, and were centrifuged for $7 \mathrm{~min}$ at $16,435 \mathrm{~g}$. The supernatant $(50 \mu \mathrm{L})$ was transferred to a new tube. Sample aliquots $(15 \mu \mathrm{L})$ were mixed with $1.5 \mu \mathrm{L} 0.1 \%$ blue bromophenol stain $(\mathrm{m} / \mathrm{v})$, and were subjected to $0.6 \%$ agarose gel electrophoresis in TAE $1 \mathrm{X}$ buffer at $7 \mathrm{~V} / \mathrm{cm}^{2}$. The gels were stained with ethidium bromide $(0.5 \mathrm{mg} / \mathrm{L})$, visualized under UV light, and photographed with the L-PIX EX photodocumentation System (Loccus Biotechnology).

\section{Generation of AFLP data}

The AFLP technique was performed according to methods by Vos et al. (1995). Bacterium genomic DNA was quantified by Scandrop ${ }^{\circledR}$ Analytik-jena, and approximately 800-1000 ng DNA sample was digested with 5 U EcoRI (rare cuts: G/AATTC) and 5 U MseI (frequent cuts: T/TAA) in the MseI $10 \mathrm{X}$ digestion buffer, with a total volume of $20 \mu \mathrm{L}$. The digestion reactions were performed at $37^{\circ} \mathrm{C}$ for $20 \mathrm{~h}$.

The DNA fragments were purified and linked to EcoRI-1 (5'-CTCGTAGACTGCGTACC-3'), EcoRI-2 (5'-AATTGGTACGACGTC-3'), MseI-1 (5'-TACTCAGGACTCAT-3'), and MseI-2 (5'-GACGTAGAGTCCTGAG-3') adaptors at the cohesive ends. The fragments were incubated with $1.0 \mu \mathrm{L}(1 \mathrm{U}) \mathrm{T} 4$ DNA ligase, $3.0 \mu \mathrm{L}$ ultrapure water, $2.0 \mu \mathrm{L}$ T4 DNA ligase buffer (5X), $1.0 \mu \mathrm{L} 0.5 \mathrm{M} \mathrm{NaCl}, 0.5 \mu \mathrm{L}$ bovine serum

Genetics and Molecular Research 15 (4): gmr15049452 
albumin $(1 \mathrm{mg} / \mathrm{mL}), 0.5 \mu \mathrm{L} 5 \mathrm{mM}$ dithiothreitol, $1.0 \mu \mathrm{L} M s e \mathrm{I}$ adaptors, and $1.0 \mu \mathrm{L}$ EcoRI adaptors. The thermocycling protocol was as follows: $37^{\circ} \mathrm{C}$ for $3 \mathrm{~h}$, followed by $30 \mathrm{~min}$ at $17^{\circ} \mathrm{C}$ and $10 \mathrm{~min}$ at $70^{\circ} \mathrm{C}$. The pre-selective amplification was performed with $4.5 \mu \mathrm{L} \mathrm{GoTaq}{ }^{\circledR}$ Green Master mix, $0.58 \mu \mathrm{L}$ pre-selective primers $(E c o+\mathrm{A}$ and $M s e+\mathrm{C})$, and $3.0 \mu \mathrm{L}$ linking product (1:4 dilution with ultrapure water).

The pre-selective PCR amplification protocol was as follows: $72^{\circ} \mathrm{C}$ for $2 \mathrm{~min}$, followed by 20 cycles at $90^{\circ} \mathrm{C}$ for $1 \mathrm{~s} ; 56^{\circ} \mathrm{C}$ for $30 \mathrm{~s} ; 72^{\circ} \mathrm{C}$ for $2 \mathrm{~min}$, and a final cycle at $60^{\circ} \mathrm{C}$ for 30 min. Afterward, a $5-\mu \mathrm{L}$ aliquot of the pre-selective PCR was diluted in $20 \mu \mathrm{L}$ ultrapure water.

The selective reaction mixture was composed of $3.5 \mu \mathrm{L}$ GoTaq $^{\circledR}$ Green Master mix, $0.54 \mu \mathrm{L}$ of each selective primer EcoRI and MseI, and $2.5 \mu \mathrm{L}$ pre-amplified product. The thermocyling protocol was as follows: incubation at $94^{\circ} \mathrm{C}$ for $2 \mathrm{~min} ; 65^{\circ} \mathrm{C}$ for 30 $\mathrm{s}$ and $72^{\circ} \mathrm{C}$ for $2 \mathrm{~min}$; eight cycles of $94^{\circ} \mathrm{C}$ for $1 \mathrm{~s}, 64^{\circ} \mathrm{C}$ for $30 \mathrm{~s}$, and $72^{\circ} \mathrm{C}$ for $2 \mathrm{~min}$; 23 cycles at $94^{\circ} \mathrm{C}$ for $1 \mathrm{~min}, 56^{\circ} \mathrm{C}$ for $30 \mathrm{~s}$, and $72^{\circ} \mathrm{C}$ for $2 \mathrm{~min}$. A final cycle of primer combination with two or three selective nucleotides in the $3^{\prime}$-end was used to select a greater degree of polymorphism.

The three best EcoRI and MseI primer combinations were chosen for the selective reactions. EcoRI primers were marked with different fluorophores (6-FAM, NED, or HEX) that emit peaks in blue, yellow, and green lights. DNA fragments were sequenced with the automated capillary DNA sequencer (Applied Biosystems, Foster City, CA, USA).

\section{Analysis of AFLP data}

Allele genotyping using bands composed of DNA fragments ranging from 50 to 500 bp was performed with the GeneMapper 4.1 program (Applied Biosystems). All isolates of $P$. ananatis were analyzed for the presence or absence of bands ( 1 or 0 , respectively) to build a binary matrix. The number of polymorphic loci, as well as genetic diversity, analysis of molecular variance (AMOVA), and fixation index ( $\mathrm{F}_{\mathrm{ST}}$ value) were calculated using the Arlequin program version 3.0 (Excoffier et al., 2007). For the principal coordinate analysis and dendrogram, the Jaccard's genetic similarity coefficient with transformation for distance was utilized, where " $d=1-s$ ", and groupings were generated by unweighted pair-group method using arithmetic average (UPGMA) hierarchical method through the FAMD program, version 1.2 (Schlüter and Harris, 2006).

The structure 2.3.3 program (Hubisz et al., 2009) was used for analysis of the $\mathrm{k}$ number of groupings by Bayesian inference according to parameters described by Evanno et al. (2005) with 10,000 burn-ins, 10,0000 repetitions, and 20 interactions. The results for the number of groupings were analyzed following the parameters determined by Pritchard and Wen (2004) using the Structure Harvester 0.6.93 program.

\section{RESULTS}

The 90 P. ananatis bacterial isolates collected from MWS lesions in the three major maizeproducing areas in south, southeast, and central-west regions of Brazil are shown in Table 1.

The PCR products amplified via species-specific primers ANAF/ANAR confirmed the identities of $P$. ananatis isolates. The amplified fragment had an approximate size of 360 or 388 bp (Figure 1).

Genetics and Molecular Research 15 (4): gmr15049452 
Table 1. Sample collection used for studies on genetic variability with AFLP markers and plasmidial DNA extraction.

\begin{tabular}{|c|c|c|c|c|}
\hline Eco-geographical region $^{1}$ & State & City & Number & $\mathrm{ID}^{2}$ \\
\hline South & Paraná & Londrina & 13 & $1 *-13$ \\
\hline South & Paraná & Pinheirinho & 7 & $14-20$ \\
\hline South & Paraná & Campo Mourão & 25 & $21-45$ \\
\hline South & Paraná & Warta & 4 & $46-49$ \\
\hline South & Paraná & Rolândia & 4 & $50-53$ \\
\hline South & Paraná & Cafelândia & 4 & $54-57$ \\
\hline South & Paraná & Palmeirinha & 1 & 71 \\
\hline South & Paraná & Cascavel & 1 & 72 \\
\hline South & Paraná & Assis Chataubriand & 1 & 73 \\
\hline South & Paraná & Sertanópolis & 1 & 74 \\
\hline South & Paraná & Pitangueiras & 1 & 75 \\
\hline South & Paraná & Toledo & 1 & 76 \\
\hline South & Paraná & Juranda & 1 & 77 \\
\hline South & Paraná & Engenheiro Beltrão & 1 & 78 \\
\hline South & Paraná & São Miguel do Iguaçú & 1 & 79 \\
\hline South & Paraná & Peabiru & 1 & 80 \\
\hline South & Paraná & Ponta Grossa & 1 & 81 \\
\hline South & Paraná & Tamarana & 1 & 82 \\
\hline South & Paraná & II Centenário & 1 & 83 \\
\hline South & Paraná & Guaíra & 1 & 84 \\
\hline Southeast & São Paulo & Ribeirão do Sul & 2 & $67-68$ \\
\hline Southeast & São Paulo & Cândido Mota & 2 & $69-70$ \\
\hline Southeast & Minas Gerais & Sete Lagoas & 7 & $58-64$ \\
\hline Southeast & Minas Gerais & Uberlândia & 2 & $65-66$ \\
\hline Central-West & Goiás & Morrinhos & 1 & 85 \\
\hline Central-West & Goiás & Planaltinha de Goiás & 1 & 86 \\
\hline Central-West & Goiás & São João da Aliança & 1 & 87 \\
\hline Central-West & Mato Grosso & Dourados & 1 & 88 \\
\hline Central-West & Mato Grosso & Maracaju & 1 & 89 \\
\hline Central-West & Mato Grosso & Douradina & 1 & 90 \\
\hline
\end{tabular}

${ }^{1}$ Official regions of Brazil. ${ }^{2} \mathrm{ID}=$ number of isolates per locality. $* 1=\mathrm{WT} 2$ isolate used as positive control.

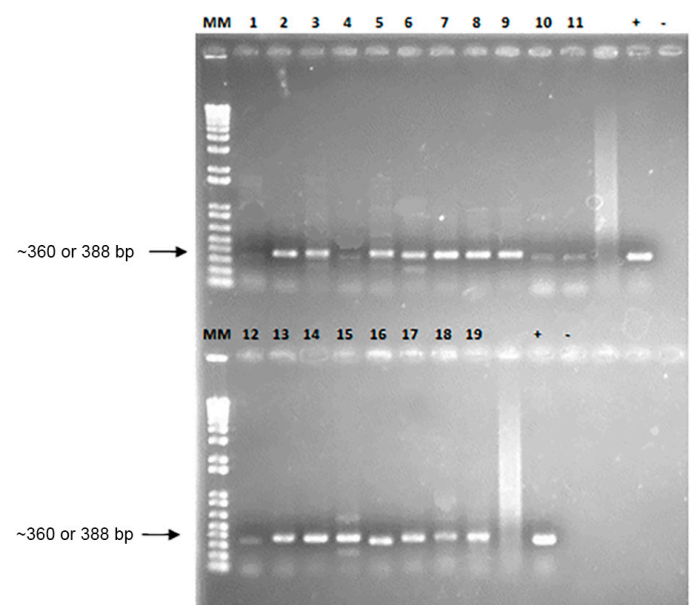

Figure 1. Identification of Pantoea ananatis isolates from MWS lesions via PCR. Products were amplified with species-specific primers (ANAF/ANAR) and were run on 1\% agarose gel. Lane MM: molecular marker $1 \mathrm{~kb}$ plus DNA ladder (Invitrogen); lanes 1 to 19: representative images from 90 isolates; "+": WT2 positive control; "“": negative control: reaction mix without DNA. Each isolate contained a single plasmid 280-352 kb in length (data not shown).

Genetics and Molecular Research 15 (4): gmr15049452 
The AFLP primer combinations EcoRI-ACG/MseI-CT, EcoRI-ACG/MseI-CAC, and EcoRI-ACG/MseI-CAG produced the highest number of scorable bands, and were used to assess genetic variability among the $P$. ananatis isolates. The selection criteria were based on the quality of the amplified products and the preliminary number of polymorphisms generated with each primer combination (Table 2). DNA fragment analysis by capillary electrophoresis under denaturing conditions in automatic sequencer showed a total of 982 bands, with an average of 327.33 bands per primer combination. Following selection, a total of 247 fragments were obtained, with an average of 82.3 bands per primer combination. Fragments between 50 and $1000 \mathrm{bp}$ were examined.

Table 2. Combinations of primers, number of amplified fragments, and percentage of polymorphic AFLP fragments using genomic Pantoea ananatis DNA.

\begin{tabular}{l|c|c}
\hline Combinations of primers & Number of amplified fragments & Polymorphic fragments (\%) \\
\hline EcoRI-ACG/MseI-CT & 93 & 89.2 \\
\hline EcoRI-ACG/MseI-CAC & 91 & 82.4 \\
\hline EcoRI-ACG/MseI-CAG & 63 & 79.3 \\
\hline
\end{tabular}

Based on genetic variability assessment via AFLP markers, the 90 P. ananatis isolates were categorized into two groups. Group I contained 60 isolates, and group II contained 30 isolates; similarities between the two groups was between 50 and $60 \%$ (Figure 2).

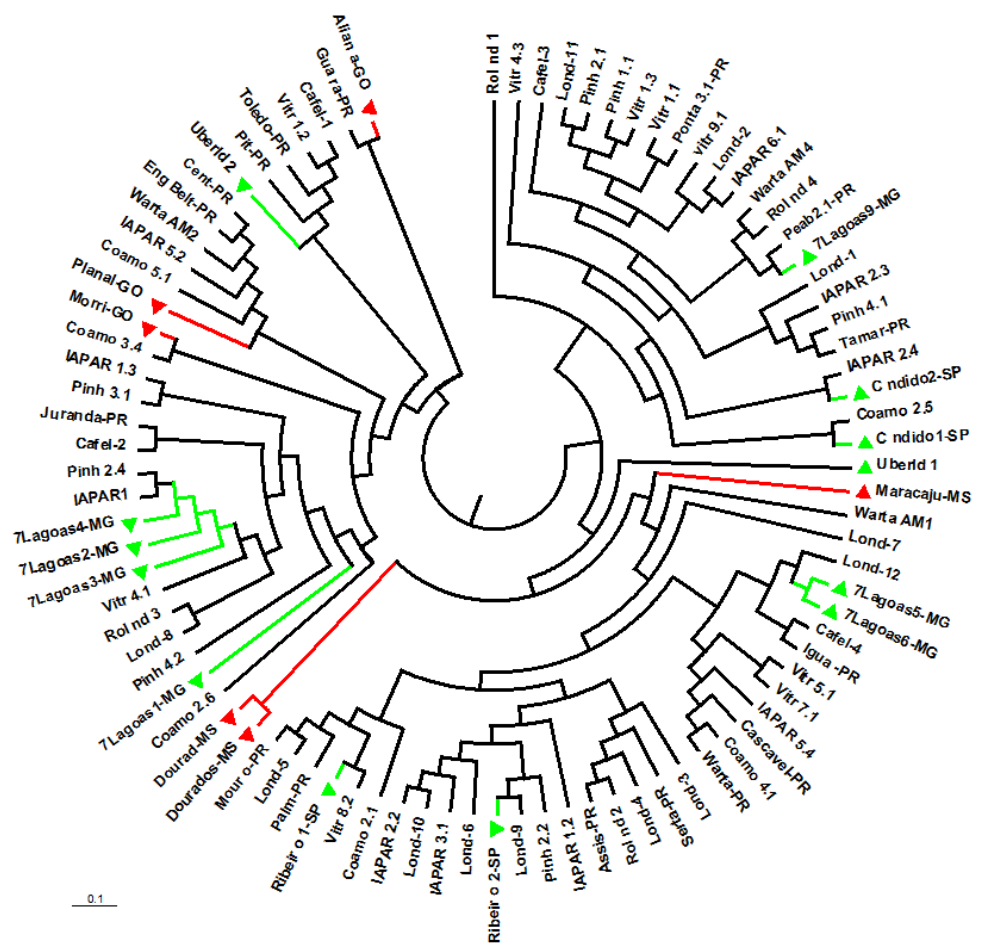

Figure 2. UPGMA dendrogram generated by AFLP data of Pantoea ananatis isolates using the Jaccard's similarity coefficient. Black, red, and green colors represent populations from southern, southeastern, and central-western regions of Brazil $(\mathrm{N}=90)$.

Genetics and Molecular Research 15 (4): gmr15049452 
Figure 3 shows the dispersion and groupings of $P$. ananatis isolates through principal coordinate analysis (PCO). As shown in the figure, the genetic distances matrix confirmed the existence of two groups (I and II).

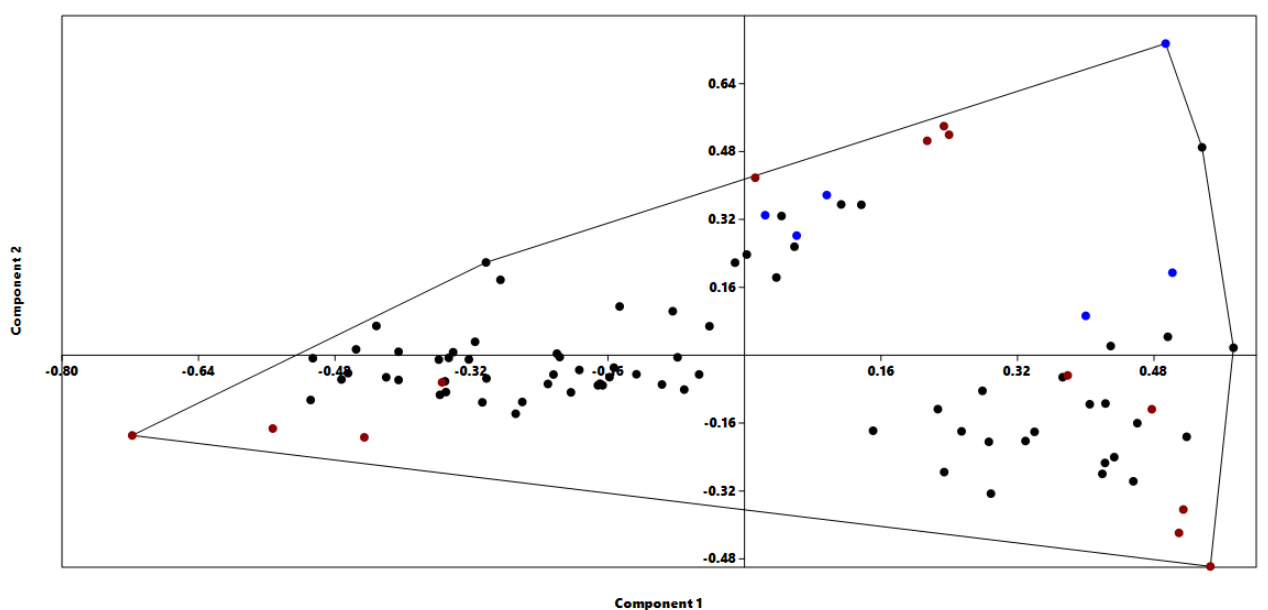

Figure 3. Main coordinate calculated from Jaccard's genetic similarity coefficient for Pantoea ananatis isolates from three eco-geographical regions of Brazil. Black, red, and blue colors represent populations from southern, southeastern, and central-western regions of Brazil $(\mathrm{N}=90)$. Refer to Table 1 for information on the isolates.

Data arranged according to eco-geographical regions is shown in Table 1. The number of possible groupings estimated by Bayesian population analysis revealed the existence of two genetic populations or groups as well (Figure 4). Each cluster corresponds to a group of genetically similar isolates. Therefore, both the dendrogram (Figure 2) and PCO analysis (Figure 3) confirmed the differences between the two groups.

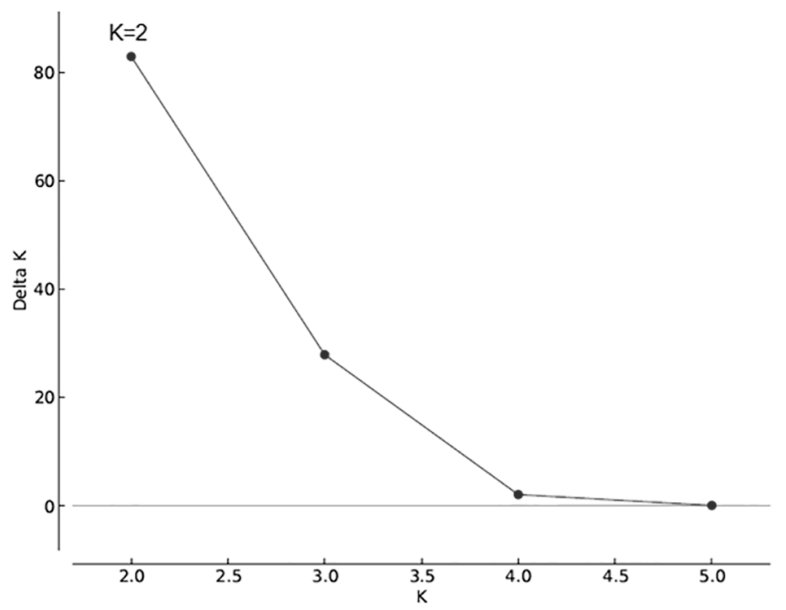

Figure 4. Estimate of grouping numbers $(\mathrm{K})$ by analysis of population structure of Pantoea ananatis of three ecogeographical regions of Brazil.

Genetics and Molecular Research 15 (4): gmr15049452 
The percentage of polymorphism in the $P$. ananatis populations with AFLP markers were $92.46,35$, and $24.4 \%$ for south, southeast, and central-west regions, respectively (Table 3). The level of genetic diversity in these populations varied from 0.07 to 0.09 (Table 3 ).

Table 3. Genetic variability of Pantoea ananatis in maize-producing areas of southern, southeastern, and central-western eco-geographical regions of Brazil.

\begin{tabular}{l|c|c|c|c}
\hline Eco-geographical origin of $P$. ananatis isolates & $\mathrm{N}^{*}$ & Polymorphic loci & Polymorphism (\%) & Genetic diversity (Hs) \\
\hline South & 71 & 908 & 92.46 & 0.092 \\
\hline Southeast & 13 & 344 & 35.03 & 0.079 \\
\hline Central-West & 6 & 242 & 24.64 & 0.090 \\
\hline Total & 90 & 982 & & \\
\hline
\end{tabular}

$* \mathrm{~N}=$ Number of Pantoea ananatis isolates from each eco-geographical region.

AMOVA showed that most of the genetic variabilities in isolates $(99.18 \%)$ resided within populations, and only low levels of genetic differentiation $(<1 \%)$ were found between populations (Table 4).

Table 4. Analysis of molecular variance (AMOVA) based on AFLP markers of three populations of Pantoea
ananatis.
\begin{tabular}{l|c|c|c|c}
\hline Variation source & d.f. & Sum of squares & Components of variance & Variance percentage \\
\hline Among populations & 2 & 100.191 & 0.366 & 0.82 \\
\hline Within populations & 87 & 3852.687 & 44.283 & 99.18 \\
\hline Total & 89 & 3952.878 & 44.650 & \\
\hline
\end{tabular}

\section{DISCUSSION}

The groupings of $P$. ananatis isolates showed that collection sites are not the main factor that determines genetic similarity between isolates. Studies on Xanthomonas arboricola pv.juglandis (Loreti et al., 2001) and Xanthomonas axonopodis pv. passiflorae (Gonçalves and Rosato, 2000) showed that genetic variability in these bacterial groups arises due to the ecogeographical origins of the isolates. In a study using random amplified polymorphic markers to assess the genetic diversity of 50 pathogenic isolates of $X$. axonopodis pv. passiflorae sampled from four similar eco-geographical regions, no correlation was found between location and grouping (Nakatani et al., 2009). Similarly, although we collected $P$. ananatis samples from three different eco-geographical regions, there was no evident relationship between the collection sites and group composition (Figure 3).

Lana et al. (2012), using rep-PCR, reported high genetic variability among Pantoea ananatis, Pantoea dispersa, and Pantoea agglomerans isolated from maize MWS lesions and MWS-like lesions in sorghum and crabgrass. The $P$. ananatis isolates (13 from maize, 1 from sorghum and crabgrass each) were clustered in a single group showing a $65-90 \%$ genetic similarity. One of the $P$. ananatis isolates was grouped with $P$. dispersa. The authors also reported that genetic variability analyzed with rep-PCR was not sufficient to differentiate the $P$. ananatis isolates based on their respective hosts or hypersensitive responses to tobacco plants.

In the present study, $\mathrm{F}_{\mathrm{ST}}$ value of 0.01 (Table 4 ) was statistically not different from zero, indicating that there was no genetic differentiation among the three $P$. ananatis populations. The low variability and genetic diversity among the sampled regions, as well as the existence of only two population groups in all isolates further strengthened the hypothesis that there was low degree of genetic differentiation in these three populations.

Genetics and Molecular Research 15 (4): gmr15049452 
Wickert et al. (2007) postulated that the majority of bacterial populations with high degrees of genetic variability are better adapted to survive in different environments, which can enhance their pathogenic capacity. However, our study results showed that $P$. ananatis exhibit low variability, but high adaptation capacity and high pathogenicity in different environments and eco-geographical regions. Understanding of evolutionary strengths that control pathogen populations is essential to the development and implementation of effective and long-lasting measures to control MWS. Therefore, further studies are necessary to clarify the evolutionarily preserved strengths of Brazilian P. ananatis populations.

According to Clark and Hartl (2010), low gene flow among populations can prevent significant genetic divergence in bacterial populations despite its relatively small effect on homogenization of allelic frequencies. In these organisms, the primary consequence of gene flow is that certain cells acquire adaptive advantages through horizontal gene transfer (HGT), such as resistance to antibiotics, or the ability to utilize other carbon sources (Freeman and Herron, 2009). HGT is common among divergent bacterial strains. According to Freeman and Herron (2009), some bacterial genomes involved in HGT may diverge in up to $16 \%$, and the lateral gene transfer among different genera generate extremely dynamic genomes containing a substantial number of insertions and deletions in chromosomal DNA. In addition, this mechanism also changes the ecological and pathogenic characteristics of bacterial species. Composition analyses have shown that the greater part of the bacterial genome consists of horizontally acquired genes (Ochman et al., 2000; Thomas and Nielsen, 2005).

Genetic exchange is a hallmark of bacterial genomes; any DNA segment can be horizontally transferred among bacterial populations, and the new DNA will be passed on to subsequent generations. However, physiological, environmental, or genetic modulations may limit the rate of horizontal gene acquisition by a particular bacterium (Arber, 2000).

In our study, comparison in genetic diversity $(\mathrm{Hs})$ between the three populations showed very similar values (Table 3 ). Although the small sampling sizes from the southern (13 isolates, approximately $14.4 \%$ sampling intensity) and central-western (6 isolates, approximately $6.7 \%$ sampling intensity) regions may lead to an underestimation in genetic variability, we collected 71 isolates (approximately 79\% sampling intensity) from the southern region, which also showed low variability. Therefore, it was unlikely that sampling size was a confounding factor that led to the low genetic variability in the $P$. ananatis populations. Comparative genomics analysis of closely related $P$. ananatis strains isolated from the same niche and maize seeds but showing distinct interaction strategies with the host plant (pathogenic, commensal, and growth-promoting) have highly similar genomes, but differed in genes that encode proteins of the secretion systems, putative effectors, transposase, integrases, and phage related genes (Sheibani-Tezerji et al., 2015). The present results indicate that genetic homogeneity found in $P$. ananatis isolates may reflect the role of accessory genes in conferring the pathogenic specialization of $P$. ananatis to reside in the maize plant environment. According to Nei (1978), the number of individuals required for estimating average heterozygosity and genetic distance in diploid populations can be very small if a large number of loci are studied and the average heterozygosity is low. The $P$. ananatis core genome is comprised of 3876 protein-coding sequences, which are conserved among unrelated populations (De Maayer et al., 2014). In the present study, 247 DNA bands revealed 982 polymorphic loci, which may correspond to approximately $22 \%$ of coding sequences of the $P$. ananatis genome (approximately 4542 genes). Thus, we postulated that sample size would not interfere with detectable level of variability among $P$. ananatis populations living in the same niche, even when isolates from highly heterogeneous environments were compared.

Genetics and Molecular Research 15 (4): gmr15049452 
The complete genome sequencing of $P$. ananatis isolated from rice revealed the existence of a 281-kb plasmid (Choi et al., 2012). De Maayer et al. (2012) also found a common plasmid, LPP-1, in seven Pantoea spp. The plasmid size varies between 281 and $794 \mathrm{~kb}$ in size, and represents $5.6-12.6 \%$ of the total bacterial genome, indicating that the accessory genome participates significantly in Pantoea sp genotype. In the same study, a single plasmid of $354.8 \mathrm{~kb}$ was observed in $P$. ananatis growing epiphytically on maize plants.

According to Llop et al. (2012), plasmids contain versatile bacterial genomes, and acquisition of extra-chromosome genetic elements is an important source of genetic diversification in phytopathogenic bacteria. Plasmids can be transferred between strains, species, and genera, and then passed down through the bacterial strain. Therefore, plasmid acquisition may contribute to bacterial survival under specific environmental conditions and enable colonization of new niches.

According to De Maayer et al. (2012), the genes carried by P. ananatis plasmids can assign several phenotypes to the bacterium, including the production of hormones, toxins, and virulence factors that contribute to its pathogenesis and host range, resistance to antibiotics and heavy metals, as well as its survival under adverse conditions. Moreover, the presence of the LPP-1 plasmid is common to all members of the Pantoea genus, suggesting that this plasmid is stably inherited and preserved in the Pantoea spp (De Maayer et al., 2012). The LPP-1 plasmid contains a basic set of preserved genes important for ecological and biological adaptation of the Pantoea ssp, and must be carefully considered in the development of measures for MWS disease control.

Our results demonstrated that $P$. ananatis strains are genetically homogeneous when they occupy the same ecological niche, in spite of diverse geographic origins and highly heterogeneous environments. These results are in agreement with previous findings, which suggested that $P$. ananatis stains colonizing the same ecological niche displayed low levels of genetic variability (Sheibani-Tezerji et al., 2015).

The knowledge on the variability of pathogens is essential for the implementation of sustainable strategies for disease control, and can lead to efficient breeding programs to confer genetic resistance.

\section{Conflicts of interest}

The authors declare no conflict of interest.

\section{ACKNOWLEDGMENTS}

We thank the Laboratory of Molecular Genetics of Londrina State University for the technical support. Research supported by Coordenação de Aperfeiçoamento de Pessoal de Nível Superior (CAPES), Conselho Nacional de Desenvolvimento Científico e Tecnológico (CNPq), and Fundação Araucária.

\section{REFERENCES}

Arber W (2000). Genetic variation: molecular mechanisms and impact on microbial evolution. FEMS Microbiol. Rev. 24: 1-7.http://dx.doi.org/10.1111/j.1574-6976.2000.tb00529.x

Ausubel FM, Brent R, Kingsto RE, Moore DD, et al. (1987). Current protocols in molecular biology, volume 1. Greene Publishing Associates/Wiley Interscience, New York.

Genetics and Molecular Research 15 (4): gmr15049452 
Choi O, Lim JY, Seo YS, Hwang I, et al. (2012). Complete genome sequence of the rice pathogen Pantoea ananatis strain PA13. J. Bacteriol. 194: 531. http://dx.doi.org/10.1128/JB.06450-11

Clark AG and Hartl DL (2010). Princípios de Genética de Populações. 4th edn. Editora Artmed, Porto Alegre.

De Maayer P, Chan WY, Blom J, Venter SN, et al. (2012). The large universal Pantoea plasmid LPP-1 plays a major role in biological and ecological diversification. BMC Genomics 13: 625. http://dx.doi.org/10.1186/1471-2164-13-625

De Maayer P, Chan WY, Rubagotti E, Venter SN, et al. (2014). Analysis of the Pantoea ananatis pan-genome reveals factors underlying its ability to colonize and interact with plant, insect and vertebrate hosts. BMC Genomics 15: 404. http://dx.doi.org/10.1186/1471-2164-15-404

Evanno G, Regnaut S and Goudet J (2005). Detecting the number of clusters of individuals using the software STRUCTURE: a simulation study. Mol. Ecol. 14: 2611-2620. http://dx.doi.org/10.1111/j.1365-294X.2005.02553.x

Excoffier L, Laval G and Schneider S (2007). Arlequin (version 3.0): an integrated software package for population genetics data analysis. Evol. Bioinform. Online 1: 47-50.

Figueiredo JEF and Paccola-Meirelles LD (2012). Simple, rapid and accurate PCR-based detection of Pantoea ananatis in maize, sorghum and Digitaria sp. J. Plant Pathol. 94: 663-667.

Freeman S and Herron JC (2009). Análise Evolutiva. 4th edn. Editora Artmed, Porto Alegre.

Gonçalves ER and Rosato YB (2000). Genotypic characterization of xanthomonad strains isolated from passion fruit plants (Passiflora spp.) and their relatedness to different Xanthomonas species. Int. J. Syst. Evol. Microbiol. 50: 811821.http://dx.doi.org/10.1099/00207713-50-2-811

Gonçalves RM, Figueiredo JEF, Pedro ES, Meirelles WF, et al. (2013). Etiology of phaeosphaeria leaf spot disease of maize. J. Plant Pathol. 95: 559-569.

Hanage WP, Fraser C and Spratt BG (2006). The impact of homologous recombination on the generation of diversity in bacteria. J. Theor. Biol. 239: 210-219. http://dx.doi.org/10.1016/j.jtbi.2005.08.035

Hara Y, Kadotani N, Izui H, Katashkina JI, et al. (2012). The complete genome sequence of Pantoea ananatis AJ13355, an organism with great biotechnological potential. Appl. Microbiol. Biotechnol. 93: 331-341.http://dx.doi.org/10.1007/ $\underline{\mathrm{s} 00253-011-3713-5}$

Hubisz MJ, Falush D, Stephens M and Pritchard JK (2009). Inferring weak population structure with the assistance of sample group information. Mol. Ecol. Resour. 9: 1322-1332.http://dx.doi.org/10.1111/j.1755-0998.2009.02591.x

Jackson RW, Vinatzer B, Arnold DL, Dorus S, et al. (2011). The influence of the accessory genome on bacterial pathogen evolution. Mob. Genet. Elements 1: 55-65. http://dx.doi.org/10.4161/mge.1.1.16432

Kado CI and Liu ST (1981). Rapid procedure for detection and isolation of large and small plasmids. J. Bacteriol. 145: $1365-1373$.

Lana UGP, Gomes EA, Silva DD, Costa RV, et al. (2012). Detection and molecular diversity of Pantoea ananatis associated with white spot disease in maize, sorghum and crabgrass in Brazil. J. Phytopathol. 160: 441-448. http:// dx.doi.org/10.1111/j.1439-0434.2012.01924.x

Llop P, Barbé S and López MM (2012). Functions and origins of plasmids in Erwinia species that are pathogenic to or epiphytically associated with pome fruit trees. Trees (Berlin, Ger.) 26: 31-46.

Loreti S, Galleli A, Belisario A, Wajnberg E, et al. (2001). Investigation of genomic variability of Xanthomonas arboricola pv. juglandis by AFLP analysis. Eur. J. Plant Pathol. 107: 583. http://dx.doi.org/10.1023/A:1017951406237

Nakatani AK, Lopes R and Camargo LEA (2009). Variabilidade genética de Xanthomonas axonopodis pv. passiflorae. Summa Phytopathol. 35: 116-120. http://dx.doi.org/10.1590/S0100-54052009000200006

Nei M (1978). Estimation of average heterozygosity and genetic distance from a small number of individuals. Genetics 89: 583-590.

Ochman H, Lawrence JG and Groisman EA (2000). Lateral gene transfer and the nature of bacterial innovation. Nature 405: 299-304. http://dx.doi.org/10.1038/35012500

Oliveira E, Fernandes FT, Casela CR, Pinto NFJA, et al. (2004). Diagnose e controle de doenças na cultura do milho. In: Tecnologias de produção do milho (Galvão JCC and Miranda GV, eds.). Editora UFV, Viçosa, 226-267.

Paccola-Meirelles LD, Ferreira AS, Meirelles WF, Marriel IE, et al. (2001). Detection of a bacterium associated with a leaf spot disease of maize in Brazil. J. Phytopathol. 149: 275-279. http://dx.doi.org/10.1046/j.1439-0434.2001.00614.x

Pereira OAP, Carvalho RV and Camargo LEA (2005). Doenças do milho. In: Manual de Fitopatologia (Kimati H, Amorim L, Rezende JAM, Bergamin Filho A and Camargo LEA, eds.). Editora Ceres, São Paulo, 478-488.

Pinto NFJA and Fernandes FT (1995). Avaliação de fungicidas no controle da mancha foliar de milho causada por Phyllosticta sp. (Phaeosphaeria maydis). Fitopatol. Bras. 20: 333.

Pritchard JK and Wen W (2004). Documentation for STRUCTURE software, version 2. Available at [http://pritch.bsd. uchicago.edu].

Romeiro RS (2005). Bactérias Fitopatogênicas. 2nd edn. Editora UFV, Viçosa.

Genetics and Molecular Research 15 (4): gmr15049452 
Schlüter PM and Harris SA (2006). Analysis of multilocus fingerprinting data sets containing missing data. Mol. Ecol. Notes 6: 569-572. http://dx.doi.org/10.1111/j.1471-8286.2006.01225.x

Segerman B (2012). The genetic integrity of bacterial species: the core genome and the accessory genome, two different stories. Front. Cell. Infect. Microbiol. 2: 116. http://dx.doi.org/10.3389/fcimb.2012.00116

Sheibani-Tezerji R, Naveed M, Jehl MA, Sessitsch A, et al. (2015). The genomes of closely related Pantoea ananatis maize seed endophytes having different effects on the host plant differ in secretion system genes and mobile genetic elements. Front. Microbiol. 6: 440. http://dx.doi.org/10.3389/fmicb.2015.00440

Soares-Castro P and Santos PM (2014). Deciphering the genome repertoire of Pseudomonas sp. M1 toward b-myrcene biotransformation. Genome Biol. Evol. 7: 1-17.http://dx.doi.org/10.1093/gbe/evu254

Souza JC and Duarte JM (2002). Reação de cultivares de milho a Phaeosphaeria maydis. Cienc. Agrotec. Lavras. 26: 325-331.

Thomas CM and Nielsen KM (2005). Mechanisms of, and barriers to, horizontal gene transfer between bacteria. Nat. Rev. Microbiol. 3: 711-721. http://dx.doi.org/10.1038/nrmicro1234

Vos P, Hogers R, Bleeker M, Reijans M, et al. (1995). AFLP: a new technique for DNA fingerprinting. Nucleic Acids Res. 23: 4407-4414. http://dx.doi.org/10.1093/nar/23.21.4407

Wickert E, Machado MA and Lemos EG (2007). Evaluation of the genetic diversity of Xyllela fastidiosa strains from citrus and coffee hosts by single-nucleotide polymorphism markers. Phytopathology 97: 1543-1549. http://dx.doi. org/10.1094/PHYTO-97-12-1543

Genetics and Molecular Research 15 (4): gmr15049452 